\title{
Potential distribution of two lynx species in europe under paleoclimatological scenarios and anthropogenic climate change scenarios
}

Akin Kiraç ${ }^{1 * i \mathrm{D}}$

${ }^{1}$ Çanakkale Onsekiz Mart University, Çanakkale, Turkey

FOREST ECOLOGY

\begin{abstract}
Background: Today's European fauna was formed under the influence of Paleoclimatic change. The distribution of two wild cat species of Europe, Lynx pardinus and Lynx Iynx, 22,000 and 6,000 years ago were determined by the MaxEnt method in relation to the Paleoclimatological scenarios (LGM and Mid-Holocene) and fossil records. Then, the current climate conditions and their distributions under the effect of anthropogenic climate change scenarios were analyzed with the current existence records.

Results: It was determined that these two wild cats were distributed according to preys on which they specialized, rather than the climate change that lasted for thousands of years. It was observed that Lynx Pardinus, which specialized only on European rabbit hunting, could not expand its distribution from past to present. Lynx lynx, on the other hand, expanded its distribution throughout the Palearctic region and adapted to different ecosystem varieties by means of its specialization on many preys from mouse to moose. Based on the climate envelope model results created with the help of MaxEnt which considers anthropogenic climate change scenarios (RCP2.6, RCP4.5, RCP6.0 and RCP8.5 2070) and today's data of two existing Lynx species, suitable habitats for L. pardinus will decrease and suitable habitats will emerge in Western France. L. Iynx, on the other hand, will limit its wide distribution to the North, except for the Alps, the Carpathians and the Caucasus, which will serve as refugial areas.
\end{abstract}

Conclusion: These results therefore require that measurements such as reducing climate change impacts over the next 50 years, protecting existing and potential habitats in advance, and reducing anthropogenic impact should be enforced..

Keywords: Lynx, Fossil, Climate Envelope Model, MaxEnt, Anthropogenic Impact

\section{HIGHLIGHTS}

Climate changes during the LGM and Mid-Holocene era did not have much impact on the distribution of two Lynx species.

Since the RCP scenarios, which are predicted to take place until 2070, will affect the distribution of two Lynx species in Europe.

The existing climatic suitable habitats of Lynx pardinus will decrease and suitable habitats will emerge in the far north west of France in 2070.

Lynx lynx will be less affected by the 2070 RCP scenarios; however, its distribution will be limited to farther north.

KIRAÇ, A. Potential distribution of two Lynx species in europe under paleoclimatological scenarios and anthropogenic climate change scenarios. CERNE, v. 27, e-102517, doi: 10.1590/01047760202127012517 


\section{INTRODUCTION}

Climate is the most important environmental factor affecting the distribution of species from past to present. Climate change led to a change in biodiversity and ecosystems in the past (Radchuk et al., 2019). The fact that biodiversity is higher in some regions than in other regions indicates that climate change is not everywhere at the same speed (Sandel et al., 2011). During climate change, species can be expected to adapt to new conditions, to migrate to favorable climatic conditions, or to disappear as the adaptation-migration mechanism might fail. Species distribution models help make such interpretations because they predict the climatic niche of the species by linking geographic distribution with climatic conditions (Guisan and Thuiller, 2005; Kıraç and Mert, 2019). Modelling can be based on palaeoclimatological scenarios and future climate change scenarios to understand how species survive during historical climate change and to predict their future status (Hijmans et al., 2005; IPCC, 2013; Nogués-Bravo, 2009). Palaeoclimatological scenarios are available in Worldclim (https://www.worldclim.org) as Last Interglacial (LIG; 120,000 - 140,000 years BP), Mid-Holocene (about 6000 years ago) and the Last Glacial Maximum (about 22,000 years ago). The data of the future climate change scenarios are $\mathrm{IPPC}_{5}$ climate projections, one of the global climate models the representative concentration pathways (RCP) used in the 5th IPCC (Intergovernmental Panel on Climate Change) report (IPCC, 2013). Modelling approaches based on ecological niche factor analysis, such as climatic habitat suitability modelling, allow the estimation of the distribution of species according to current conditions and past and future projections (Nogués-Bravo, 2009; Wiens et al., 2009; Koç et al., 2018; Süel et al., 2018).

Climate changes which occurred during the quaternary period led to significant changes in the distribution of species worldwide, as evidenced by fossil records (Hewitt, 2003). The present European fauna was formed by changes in the distribution based on climate change in the Late Pleistocene and early Holocene. During this period, the Balkans, Anatolia, Greece, Italy and the Iberian Peninsula served as refugia, and many species expanded their distribution from south to north when favorable climatic conditions occurred (Hewitt, 2003). Lynx lynx (Linnaeus, 1758) and Lynx pardinus (Temminck, 1827) are two of the five wildcats in Europe with fossil records from the Late Pleistocene. During the Last Glacial Maximum period, L. Iynx and L. pardinus were seen in the Iberian Peninsula. However, only L. pardinus was recorded from the Iberian Peninsula from the Holocene period. Fossil records indicate that $L$. pardinus expanded its distribution to central and western France. Both the Last Glacial Maximum and Holocene fossils show that L. Iynx expanded its distribution to northward (Sommer and Benecke, 2006).

L. pardinus now lives in habitats dominated by Mediterranean scrubland on the Iberian Peninsula, and Oryctolagus cuniculus (European rabbit) account for 99\% of its diet (Ferreras et al., 2010). L. pardinus is in the endangered category according to the IUCN Red
List Criteria. L. Iynx is a species which adapts to different ecosystems and different climatic conditions. Therefore, it has a wide distribution as well as a wide variety of diet from mouse to moose (Von Arx et al., 2004; Mengüllüoğlu et al., 2018; Schmidt et al., 2011). However, its main prey is lagomorphs and small ungulates (Von Arx et al., 2004). For example, in Anatolia, L. Iynx lives in 3 different ecosystem types (Mediterranean, mixed forest-steppe, and subalpine ecosystems) and prefers mostly brown hare (Lepus europaeus) as a prey even in the presence of wild goat, red deer and wild boar (Mengüllüoğlu et al., 2018). According to the IUCN Red List Criteria, L. lynx is in the Least Concern category on a global scale, but in the Endangered category for the Mediterranean.

The aim of this study is to obtain information about the past distributions from the model obtained by using Palaeoclimatological scenarios and fossil records of the species and to obtain information about how they continued their distribution under the influence of Palaeoclimatological events until today. To determine the current climate conditions preferred by these two wild cat species by analyzing the relationship between living species data and current climatic conditions, and to predict how the appropriate habitats of the species may change in the face of future climate change. It is recommended that the outputs of the study be taken into account in species conservation plans.

\section{MATERIAL AND METHODS}

\section{Species data}

Since 2012, Global Biodiversity Information Facility (GBIF) has been a database that has provided access to nearly 400 million data records (Gaiji et al., 2013). L. pardinus and L. Iynx fossil location records and current location records were obtained from https://www.gbif.org. Six fossil records and 705 living records of $L$. pardinus were obtained. For L. Iynx, 13 fossil records and 1,063 living records were obtained. The fossil records of $L$. pardinus were from Spain and France. All the living records were from Spain. L. Iynxs fossil records were from Greece, Germany, Hungary, the Netherlands, the Russian Federation and Ukraine. The living records were from Central, Northern and Eastern Europe.

\section{Bioclimatic data}

Bioclimatic data (current, past and future) are available at www.worldclim.org. (Hijmans et al., 2005). The current bioclimatic data (10 arc minute) in version 1.4 were downloaded in ESRI Grid format. MPI-ESM-P-based bioclimatic data (10 arc minute) from 22,000 years ago (Last Glacial Maximum: LGM) were downloaded from the "past" section of Version 1.4. From the same section, HadGEM2ES-based bioclimatic data (10 arc minute) from 6,000 years ago (Mid-Holocene) were downloaded. The bioclimatic data based on HadGEM2-ES (2070-2100) were downloaded from the section of future conditions. The data available here are the IPPC 5 climate projections from global climate models (GCMs) for four representative concentration 
pathways (RCPs). The codes, descriptions and units of 19 bioclimatic variables are given in Tab. 1 .

\section{Climatic habitat suitability (climate envelope model) models and maps}

To eliminate the multicollinearity problem, we applied Pearson Correlation Analysis $(\mathrm{R} 2<0.8)$ for a total of 19 bioclimatic variables. However, a very high correlation was found between the bioclimate data of 10 arc minute size. For this reason, analysis was started with all bioclimate data and the bioclimate variable that did not contribute to the model and had the least contribution was not included in the next model. This process was continued until the model with the highest AUC value was obtained. Climatic habitat suitability modelling was performed with the help of MaxEnt 3.4.1 software (Phillips et al., 2006). MaxEnt is a software that predicts the distribution of species using by habitats feature and maximum entropy algorithm (Phillips et al., 2017). MaxEnt has been used in recent years to reveal

Tab. 1 Bioclimatic variables.

\begin{tabular}{ccc}
\hline Code & Bioclimatic Variables & Unit \\
\hline Bio1 & Annual Mean Temperature & ${ }^{\circ} \mathrm{C}$ \\
Bio2 & Mean Diurnal Range (Mean of monthly (max & ${ }^{\circ} \mathrm{C}$ \\
Bio3 & temp - min temp)) & \\
Bio4 & Temperature Seasonality (standard deviation & \\
Bio5 & Max Temperature of Warmest Month & C of V \\
Bio6 & Min Temperature of Coldest Month & ${ }^{\circ} \mathrm{C}$ \\
Bio7 & Temperature Annual Range (BIO5-BIO6) & ${ }^{\circ} \mathrm{C}$ \\
Bio8 & Mean Temperature of Wettest Quarter & ${ }^{\circ} \mathrm{C}$ \\
Bio9 & Mean Temperature of Driest Quarter & ${ }^{\circ} \mathrm{C}$ \\
Bio10 & Mean Temperature of Warmest Quarter & ${ }^{\circ} \mathrm{C}$ \\
Bio11 & Mean Temperature of Coldest Quarter & ${ }^{\circ} \mathrm{C}$ \\
Bio12 & Annual Precipitation & $\mathrm{mm}$ \\
Bio13 & Precipitation of Wettest Month & $\mathrm{mm}$ \\
Bio14 & Precipitation of Driest Month & $\mathrm{mm}$ \\
Bio15 & Precipitation Seasonality (Coefficient of Variation) & $\mathrm{C}$ of V \\
Bio16 & Precipitation of Wettest Quarter & $\mathrm{mm}$ \\
Bio17 & Precipitation of Driest Quarter & $\mathrm{mm}$ \\
Bio18 & Precipitation of Warmest Quarter & $\mathrm{mm}$ \\
Bio19 & Precipitation of Coldest Quarter & $\mathrm{mm}$ \\
\hline
\end{tabular}

how climate change affects species distribution (Handrick and McGarvey, 2019; Akyol and Örücü, 2019; Mahdavi et al., 2020; Qian et al., 2020). MaxEnt is also a practicable and valid method for all species (Untalan et al., 2019). In addition, MaxEnt creates habitat suitability map as the analysis result output (Elith et al., 2011). For this reason, MaxEnt was used as statistical modeling in the study.

The historical bioclimatic data (Last Glacial Maximum and Mid-Holocene) and the fossil data from two cat species were analyzed and this model, which was created through the fossil data, was called "Past Model 1". The current bioclimatic data and the presence data of two felid species were analyzed, and the "Current Model" was obtained. The current bioclimatic data, the bioclimatic data from HadGEM2-ES-based climate change scenarios (RCP2.6; RCP4.5; RCP6.0; RCP8.5) in 2070 and the presence data from two felid species were analyzed together, and the Current Model was projected into the future. Thus, the "Future Model" was created. The current bioclimatic data, the historical bioclimatic data (LGM and Mid-Holocene) and the presence data from two wildcat species were analyzed together. Thus, the Current Model was projected to the past, and the resulting model was called "Past Model 2" (Fig. 1).

The validity of the obtained models was evaluated according to the AUC values. As the AUC value approaches 1 , the model is considered to be excellent; the model is considered to be an explanatory model when the AUC value is 0.7 ; and finally, when the model AUC value is 0.5 , it is considered to be a non-informative model (Preau et al., 2018).

With the help of ArcMap 10.2 software, habitat suitability of both wild species were mapped. The areas with the highest level of suitability were colored red, and the areas with the lowest level of suitability were colored blue.

\section{RESULTS}

\section{Climatic habitat suitability model results for Lynx Iynx}

\section{Past model 1}

The Last Glacial Maximum (22000 years ago): The obtained model had an AUC value of 0.833 (Fig. 2A). Approximately 22,000 years ago, L. Iynx made its habitat preferences according to the climate variables Bio3, Bio6, Bio15, Bio18 (melgmbi3, melgmbi6, melgmbi15, melgmbi18). It has been determined that the variable that contributes

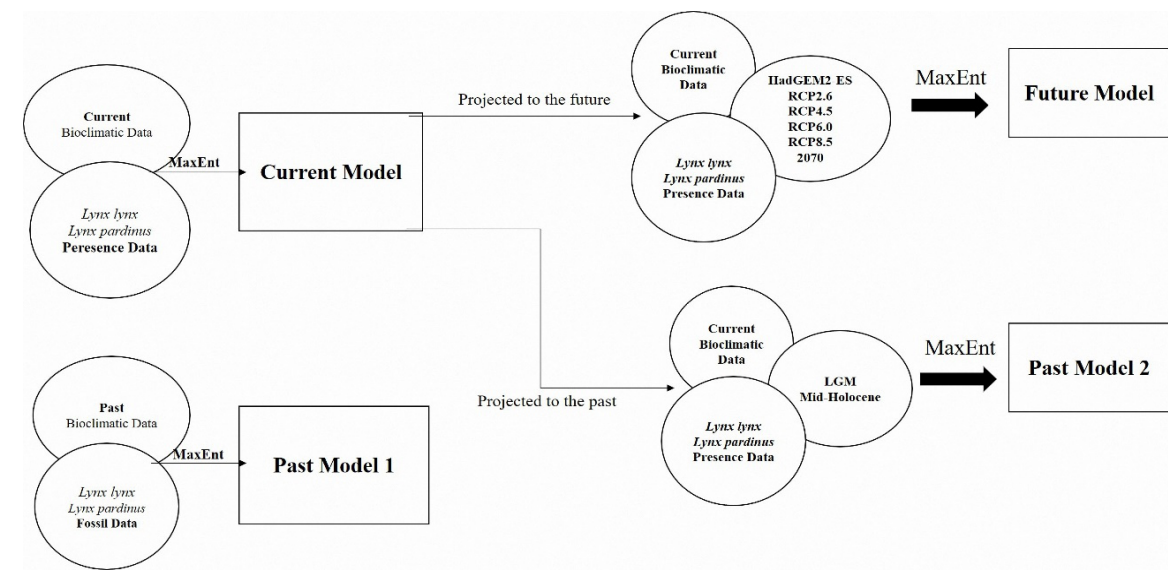

Fig. 1 Climatic habitat suitability modelling procedure. 


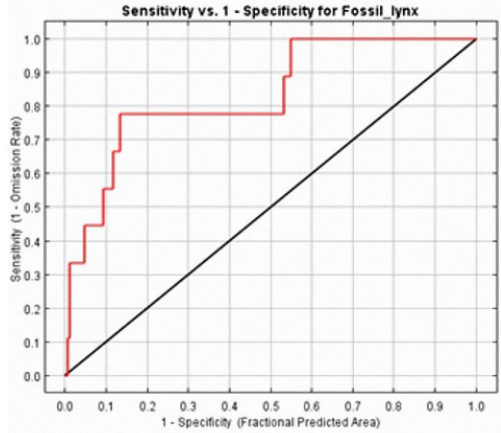

A

Training data (AUC $=0.833$ )
Random Predicton (AUC $=0.5$ )

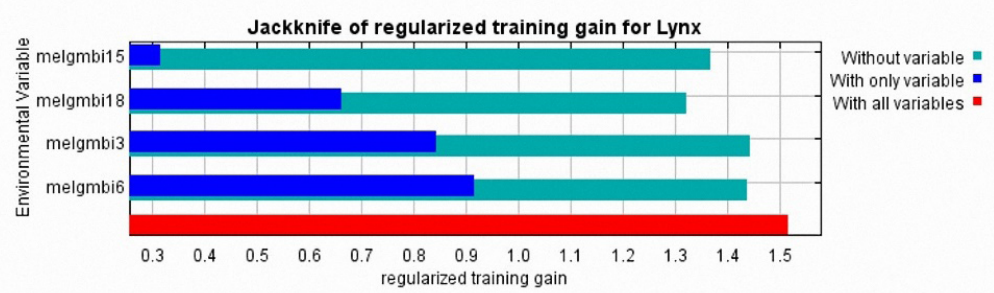

B

Fig. 2 Sensitivity vs. 1-specificity graphic and results of jackknife evaluations of relative importance of predictor variables of L.Iynx (LGM Past Model 1) A: AUC values of the Last Glacial Maximum (past model 1). B: Jackknife test for the relative importance of bioclimatic variables (Last Glacial Maximum past model 1).

the most to this model is the minimum temperature of the coldest month (melgmbi6=Bio6) (Figure 2B). According to this, L. lynx distributed 22000 years ago in areas with temperatures between -40 and $-10{ }^{\circ} \mathrm{C}$ in the coldest month of the year (Fig. 3A). In addition, L.Iynx preferred areas with a precipitation of warmest quarter of approximately $250 \mathrm{~mm}$ (Fig. 3C), a low level of temperature variability (Figure 3B) and moderate precipitation seasonality (Fig. 3D). When the map of the Past Model 1 was examined, the Mediterranean Basin, Central Europe, the Balkans, Anatolia, the Caucasus, North Africa, the Arabian Peninsula, South and West Asia had favorable climatic conditions for L. Iynx about 22,000 years ago. However, the climatic conditions of Northeastern Europe, the Alps, North Asia were not suitable for the distribution of L. Iynx (Fig. 6A).

A

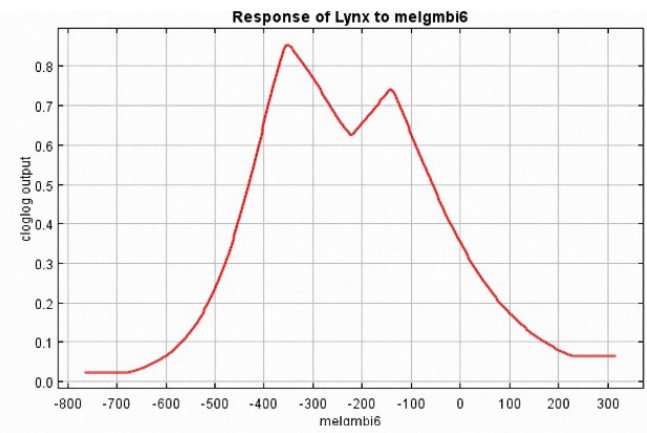

B

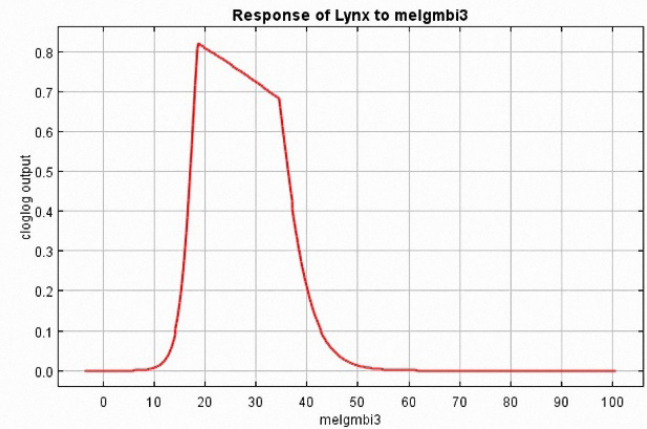

Mid-Holocene (6,000 years ago): The AUC of the model for this period is 0.841 Fig. 4A). L. Iynx was distributed in this period according to Bio3, Bio5, Bio6 and Bio18 (hemidbi3, hemidbi5, hemidbi6, hemidbi18) (Fig. 4B). It has been determined that the variable that contributes the most to this model is the minimum temperature of the coldest month (melgmbi6=Bio6) (Fig. 4B). L.Iynx continued its climate-dependent distribution in areas where the coldest month and the lowest temperature are $-10-0{ }^{\circ} \mathrm{C}$ (Fig. 5A), the temperature variability is quite low (Fig. 5B), the warmest month's highest temperature values are $15-25{ }^{\circ} \mathrm{C}$ (Figure $5 \mathrm{C}$ ), and the warmest quarter's precipitation is $0-400 \mathrm{~mm}$ (Figure 5D). When the map of the model of this period was examined, all of Europe, except for the Alpine mountains, the southern part of Scandinavia, the Balkans, Anatolia and West Asia were climatically suitable for the distribution of L. Iynx (Figure 6B).

C
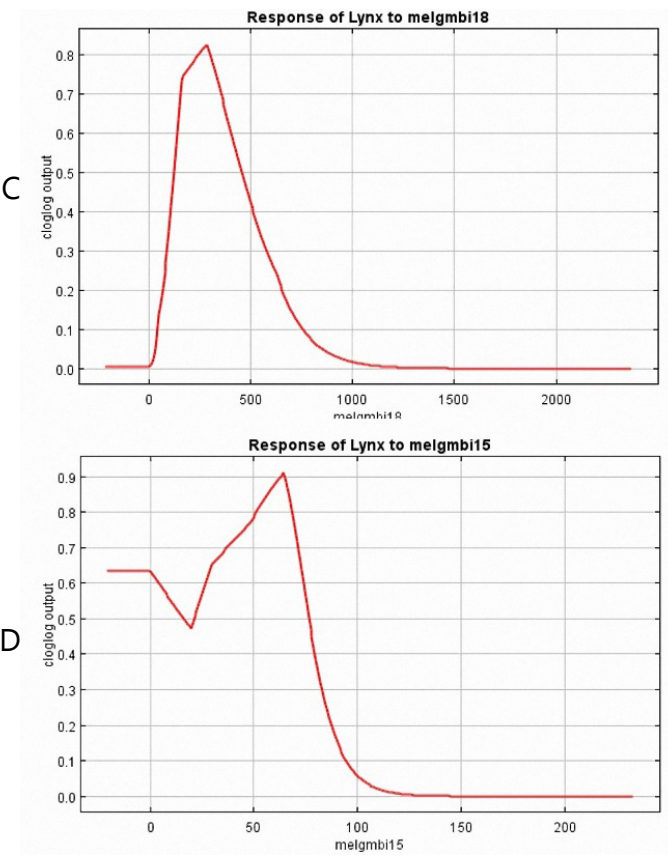

Fig. 3 Response curves from Last Glacial Maximum model (past 1 model). A: melgmbi6 (Bio6). B: melgmbi3 (Bio3). C: melgmbi18 (Bio18) D: melgmbi15 (Bio15). 


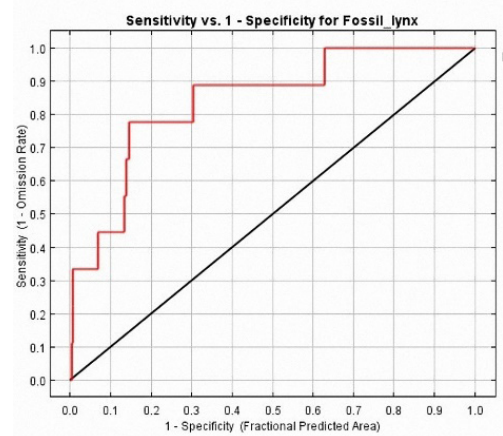

A

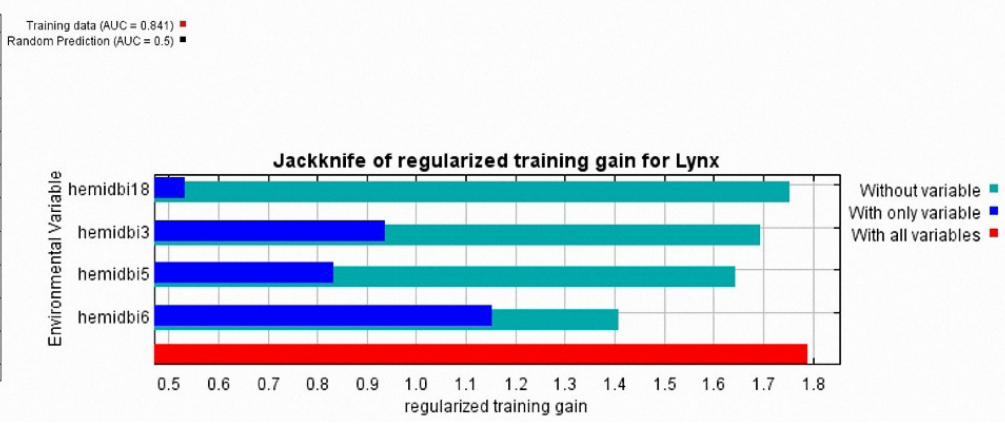

B

Fig. 4 Sensivity vs. 1-specificity graphic and results of jackknife evaluations of relative importance of predictor variables of L. Iynx (Mid-Holocene Past Model 1). A: AUC values of the Mid-Holocene (past model 1). B: Jackknife test for the relative importance of bioclimatic variables (Mid-Holocene past model 1).

\section{Current model}

The AUC value of the model which was created according to the present data is 0.934 (Fig. 7A). It is seen that the variables that contribute the most to this model are Bio1, Bio6, Bio11 and Bio15, respectively. (Fig. 7B). Today, L. Iynx maintains its distribution in areas where the annual mean temperature value is $5^{\circ} \mathrm{C}$ (Fig. $8 \mathrm{~A}$ ), the min temperature of coldest month value is $-10^{\circ} \mathrm{C}$ (Fig. $8 \mathrm{~B}$ ), the mean temperature of coldest quarter value is $-5^{\circ} \mathrm{C}$ (Fig. $8 \mathrm{C}$ ), the little variation in precipitation seasonality (Fig. 8D). When the map of the Current Model was examined, Central Europe, Alp Mountains, Scandinavia, North and Northeast Europe, Balkans, Caucasus and Northeast Anatolia were seen to be climatically suitable for the distribution of L. Iynx (Fig. 9).

A

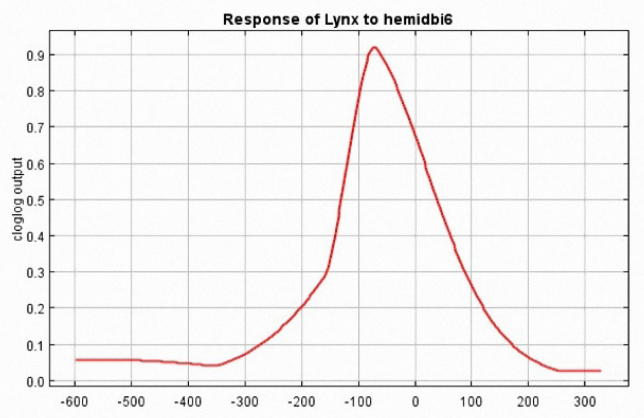

B

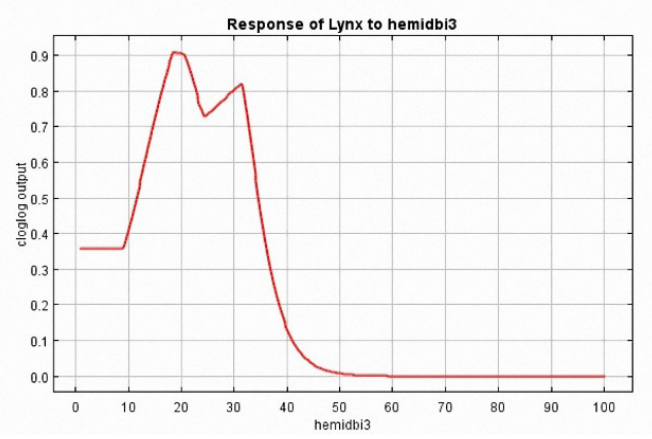

\section{Future model}

The Future Model was created by projecting the Current Model with the AUC value of 0.934 into the future. RCP 2.6 Scenarios: According to this climate scenario, favorable climatic conditions for L. Iynx will disappear in Southern and Central Europe except for the Alps in the period between 2070 and 2100. Scandinavia and North-Northeast Europe will continue to provide favorable climatic conditions. Very few habitats in the Balkans and the Caucasus will maintain favorable climatic conditions (Fig. 10A).

RCP 4.5 Scenarios: In this climate scenario, only the Alps will maintain suitable climatic conditions. In the North, new potential climatic appropriate habitats will emerge. In the Caucasus and Northeast Anatolia, suitable climatic conditions will continue in very few habitats (Fig. 10B). RCP
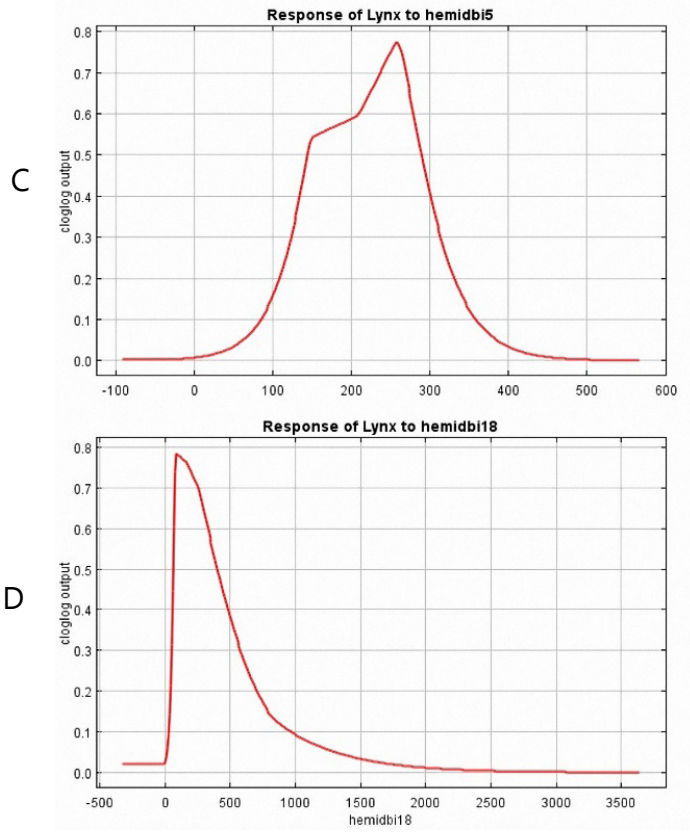

Fig. 5 Response curves from Mid Holocene (past 1) model. A: hemidbi6 (Bio6). B: hemidbi3 (Bio3). C: hemidbi5 (Bio5). D: hemidbi18 (Bio18) 


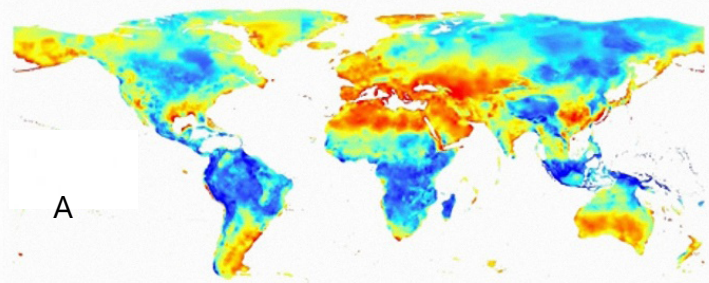

Lynx lynx

Last Glacial Maximum (about 22,000 years ago) Past Model 1

Value ${ }_{\text {High : } 1}$

Low : 0

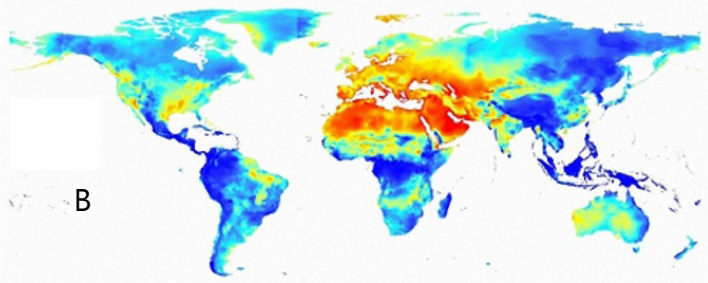

Lynx lynx

Mid-Holocene (About 6000 years ago) Past Model

Value ${ }_{\text {High : } 1}$

Fig. 6 Climatic habitat suitability maps for Lynx lynx. A: LGM past model 1. B: Mid-Holocene past model 1.

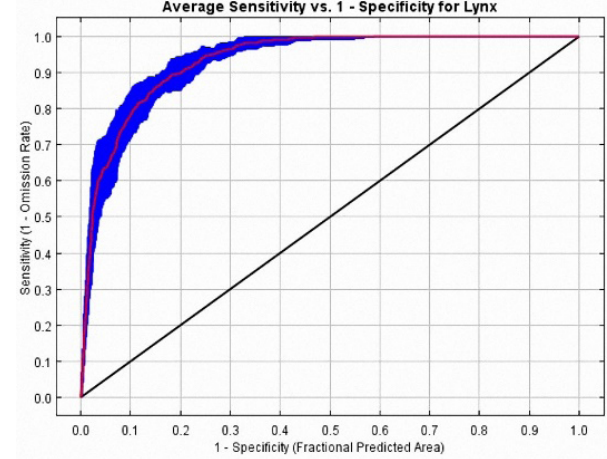

A

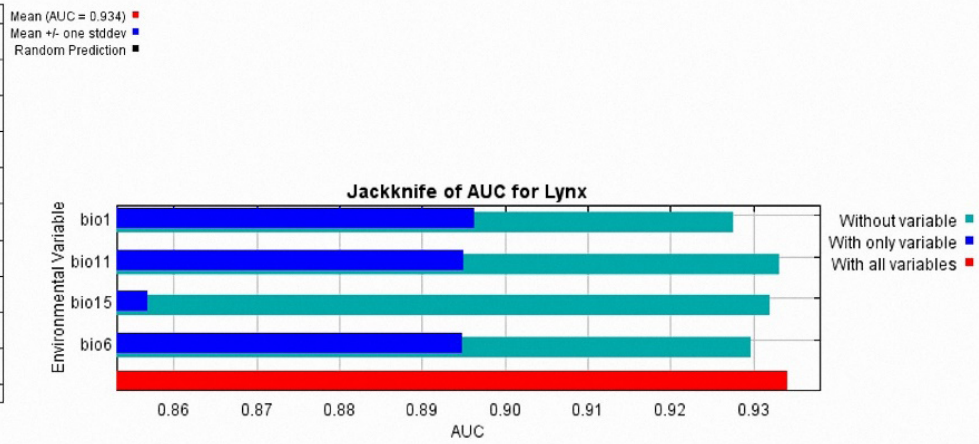

B

Fig. 7 Sensitivity vs. 1-specificity graphic and results of jackknife evaluations of relative importance of predictor variables of L.Iynx (Current Model) A: AUC values of the Current Model. B: Jackknife test for the relative importance of bioclimatic variables (Current Model).

A

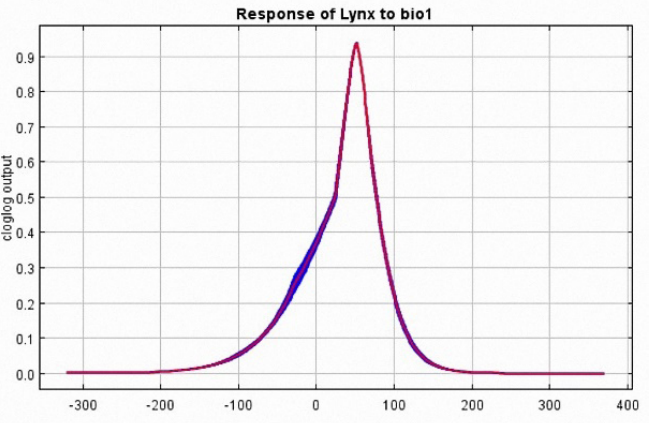

B

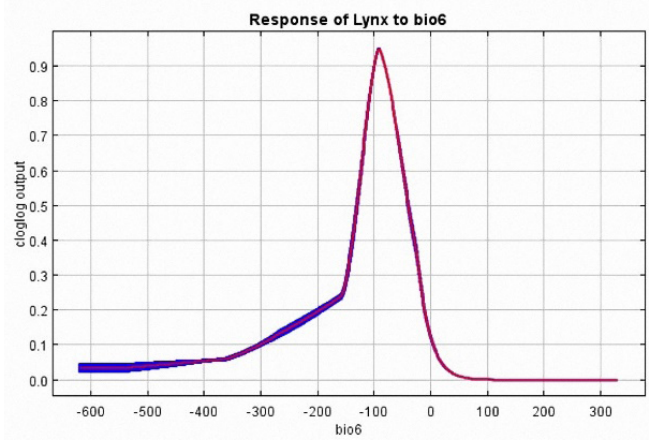

C
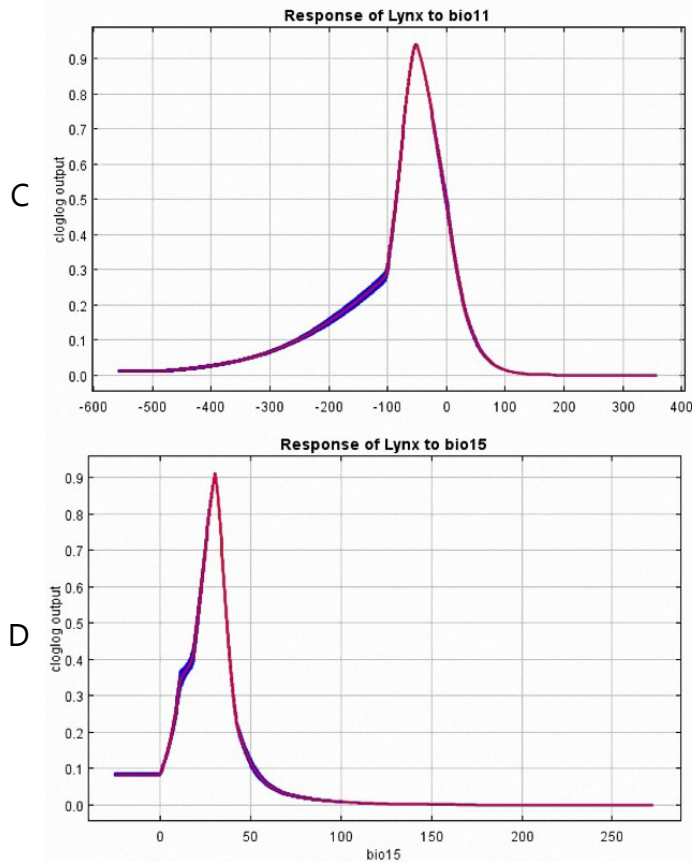

Fig. 8 Response curves from Current Model. A: Bio1. B: Bio6. C: Bio11. D: Bio15. 


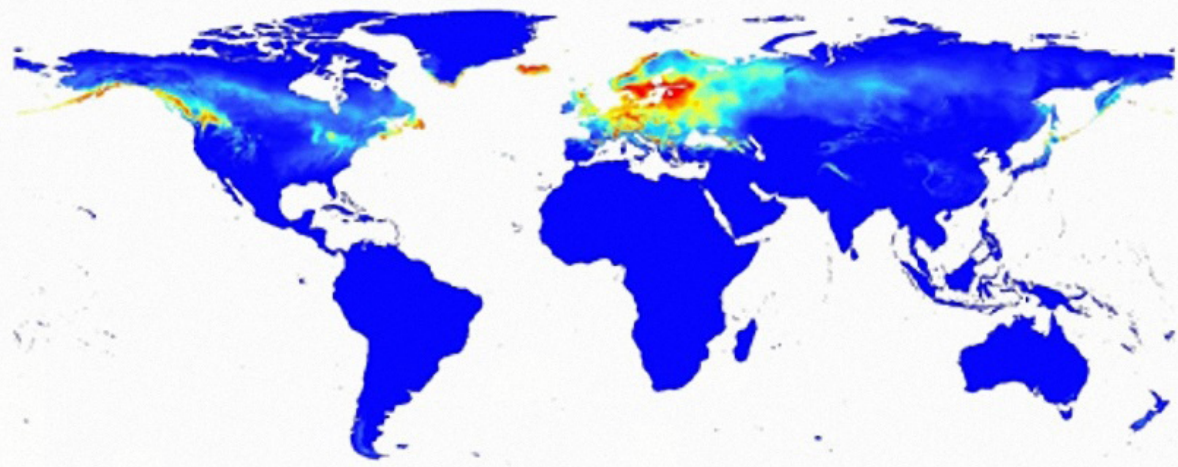

Fig. 9 Climatic habitat suitability maps for Lynx lynx current model.

\section{Lynx lynx}

\section{Current \\ Value

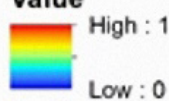

6.0 Scenarios: Fig 2 shows that, unlike the RCP 4.5 scenario, a small proportion of habitats that provide favorable climatic conditions will decrease in the Alps (Fig. 10C). RCP 8.5 Scenarios: According to this scenario, the suitable climatic conditions for L. Iynx will be entirely in the north. In the south, only the Alps and the Caucasus will maintain suitable climatic conditions (Fig. 10D).

\section{Past model 2}

The Past Model 2 was created by projecting the Current Model into the past. Last Glacial Maximum $(22,000$ years ago): When the map of this model was examined, it was seen that there were suitable climatic conditions in the past for L. Iynx in Southern Europe, Balkans, North Anatolia and Caucasus. The Alps became a barrier to northward distribution 22,000 years ago (Fig. 11A). Mid-Holocene

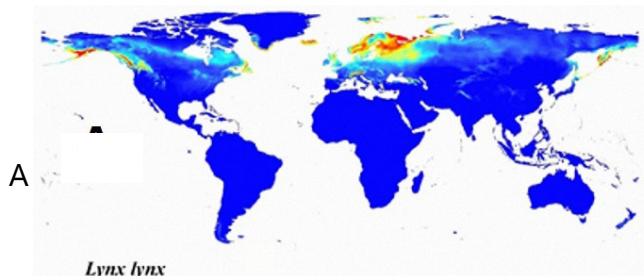

Lynx lynx

RCP 2.62070

Value ${ }_{\text {High : } 1}$
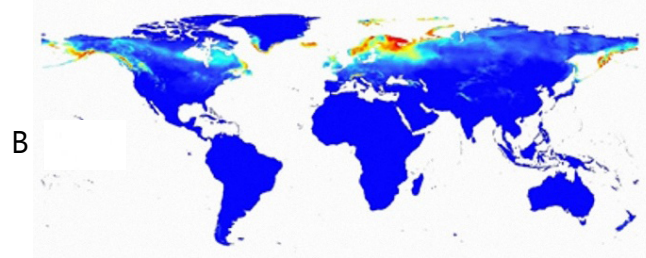

Lynx lynx

RCP 6.02070

Value ${ }_{\text {High : : }}$
(6,000 years ago): According to this historical climate scenario, suitable climatic conditions emerged in the Alps, North Europe and Scandinavia (Fig. 11B).

Climatic habitat suitability model results for Lynx pardinus

\section{Past model 1}

Last Glacial Maximum (22,000 years ago): The AUC value of this model is 0.987 (Fig. 12A). Bioclimatic variables affecting the habitat preference of $L$. pardinus in this period were Bio3, Bio4, Bio9, Bio15 and Bio18 (melgmbi3, melgmbi4, melgmbi9, melgmbi15, melgmbi18) (Fig. 12B). It is seen that the variable that contributes the most to the model is Bio9 (melgmbi9) and the variable that does not contribute at all is Bio3 (melgmbi3). Twenty two thousand years ago,

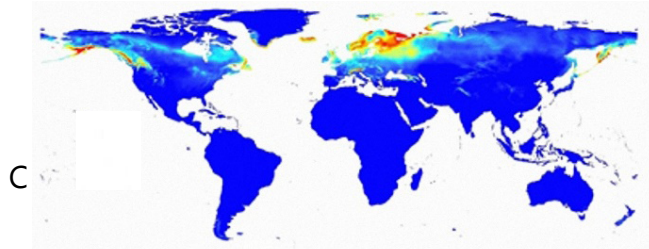

$$
\begin{aligned}
& \text { Lynx lynx } \\
& \text { RCP } 2.62070 \\
& \text { Value } \\
& \text { High: } 1 \\
& \text { Low : } 0
\end{aligned}
$$

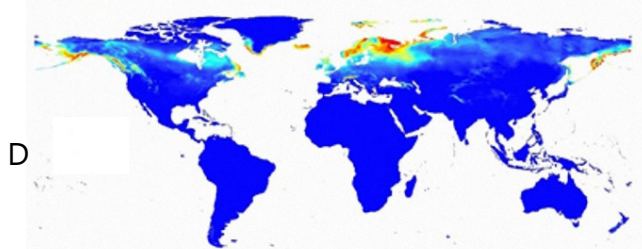

Lynx lynx

RCP 6.0 2070

Value ${ }_{\text {non : }}$

Fig. 10 Climatic habitat suitability maps for Lynx lynx. A: RCP2.6 2070. B: RCP4.5 2070. C: RCP6.0 2070. D: RCP8.5 2070. 


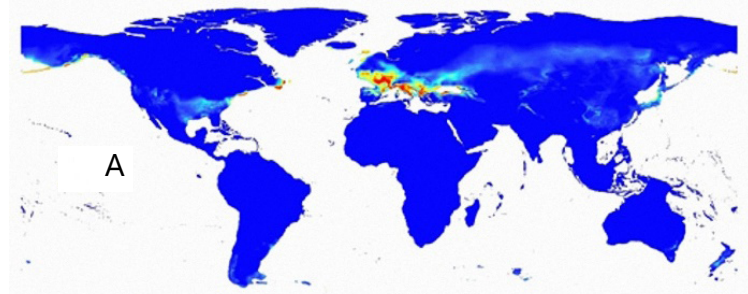

Lynx lynx

Last Glacial Maximum (about 22,000 years ago) Past Model 2

Value

High: 1

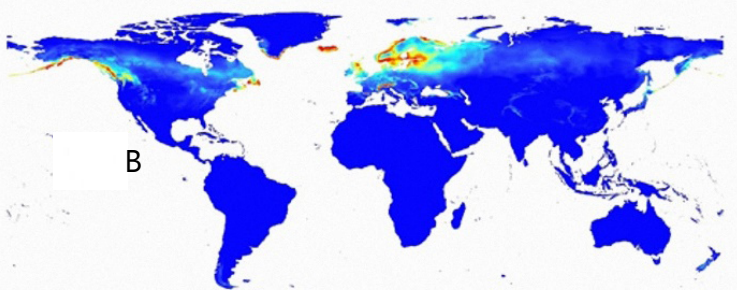

Lynx lynx

Mid-Holocene (About 6000 years ago) Past Model 2

Value

High : 1

Fig. 11 Climatic habitat suitability maps for lynx lynx. A: LGM past model 2. B: Mid-holocene past model 2.

L.pardinus continued its distribution in areas where mean temperature of driest quarter value was $20{ }^{\circ} \mathrm{C}$ (Fig. 13A), precipitation total variation was low (Fig. 13B), seasonal temperature variation was low (Fig. 13C), precipitation of warmest quarter value was 0-500 mm (Fig. 13D).

When the map of this model was examined, the Iberian Peninsula, France, South Europe, especially Italy and Greece, North Africa, Anatolia and West Asia were seen to have provided suitable climatic conditions for $L$. pardinus. In this period, no suitable climatic conditions were found in the north for L. pardinus (Fig. 16A). MidHolocene (6,000 years ago): The AUC value of the model created for this period is 0.927 (Fig. 14A). Six thousand years ago, habitats formed by Bio9, Bio18 and Bio15 bioclimatic variables were suitable for L. pardinus (Fig. 14B). According to the model belonging to this period, suitable habitats for L.pardinus were in areas where mean temperature of driest quarter value was $20-40{ }^{\circ} \mathrm{C}$ (Fig. 15A), precipitation of warmest quarter value was between 0-250 mm (Fig. 15B) and variation in precipitation amount was low (Fig. 15C). According to the climatic habitat suitability map obtained, it was seen that there were areas suitable for the distribution of $L$. pardinus in the Mediterranean Basin, the Balkans, Anatolia and West Asia (Fig. 16B).

\section{Current model}

The AUC value of the model, which was created with current climate conditions and the current presence data, is 0.988 (Fig. 17A). Today, L. pardinus prefers habitats under the influence of climatic variables such as Bio3 Bio4, Bio18 and Bio19 (Fig. 14B). It has been determined that the habitats in which L.pardinus habitats today consist of areas with a smaller level of temperature variability (Fig. 18A), almost no precipitation in the hottest three months (Fig. 18B), low seasonal temperature variation (Fig. 18C), and precipitation of the coldest quarter value between 100-400 mm (Fig. 18D). These suitable habitats are found mainly in Spain and potentially in Northwest Africa, Greece and Anatolia (Figure 19).

\section{Future model}

The Future Model was created by projecting the Current Model with the AUC value of 0.988 into the future. According to the future climate scenarios, RCP 2.6, RCP 4.5 and RCP 6.0, there will be a slight disintegration and loss in the existing and potential habitats of $L$. pardinus. Unlike today and three other future climate change scenarios, according to the RCP 8.5 scenario, fragmentation and loss of $L$. pardinus habitats will be greater and favorable climatic conditions will shift to the North in 2070 (including France) (Fig. 20).

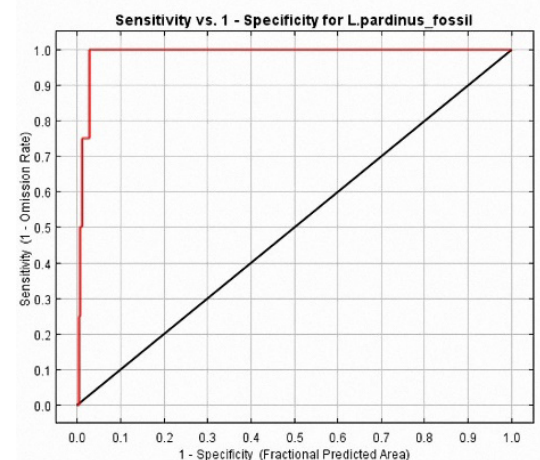

A Training data (AUC $=0.987$ )
Random Prediction $(A \cup C=0.5)$

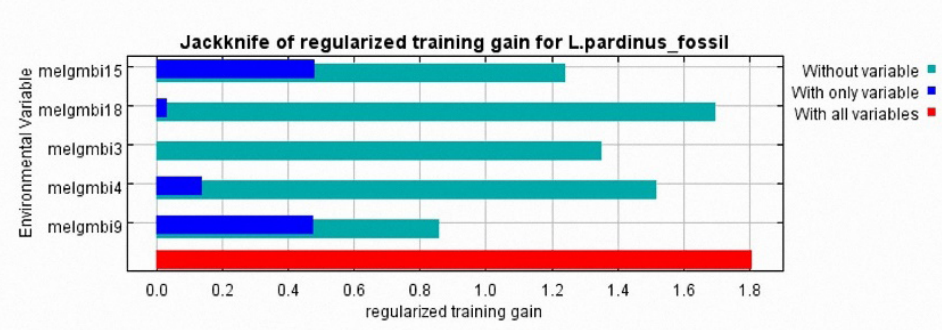

B

Fig. 12 Sensitivity vs. 1-specificity graphic and results of jackknife evaluations of relative importance of predictor variables of L.pardinus (LGM Past Model 1) A: AUC values of the Last Glacial Maximum (past model 1). B: Jackknife test for the relative importance of bioclimatic variables (Last Glacial Maximum past model 1). 
A

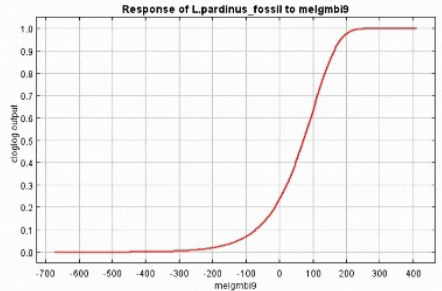

B

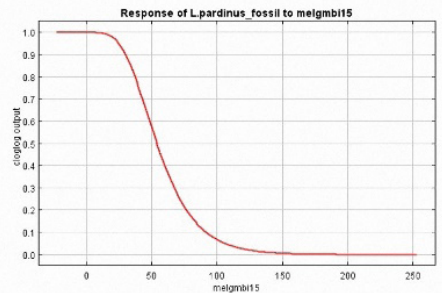

C

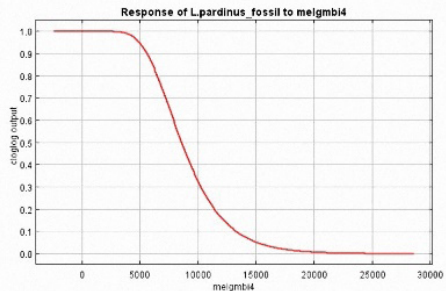

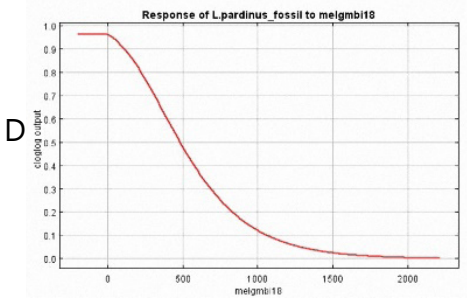

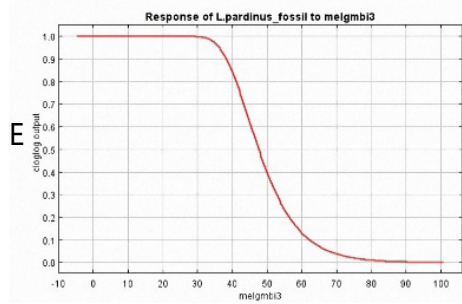

Fig. 13 Response curves from Last Glacial Maximum (past model 1). A: melgmbi9 (bio9). B: melgmbi15 (Bio15). C: melgmbi4 (Bio4). D: melgmbi18 (Bio18). E: melgmbi3 (Bio3).

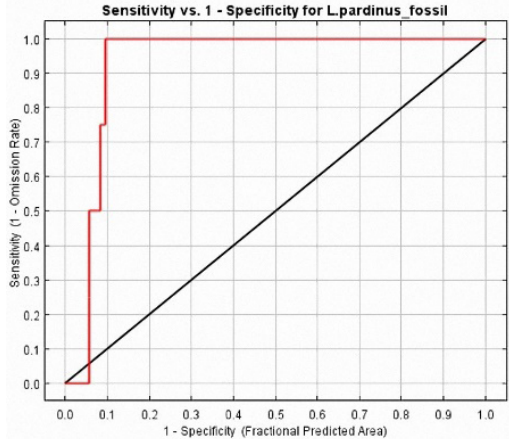

A

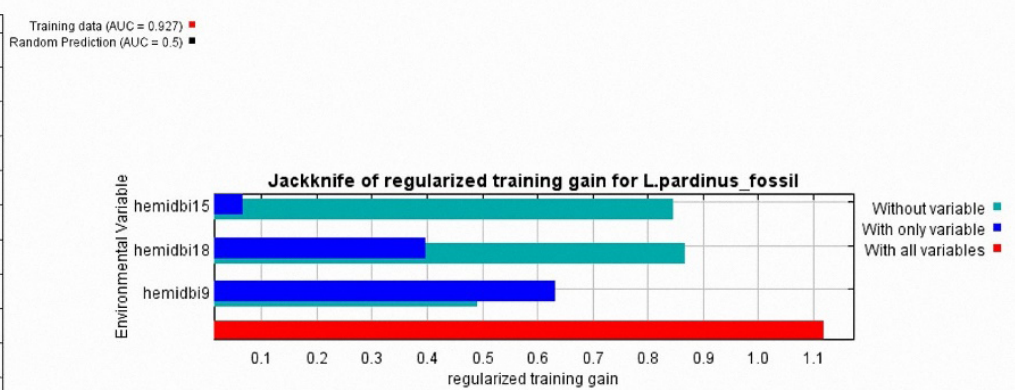

B

Fig. 14 Sensitivity vs. 1-specificity graphic and results of jackknife evaluations of relative importance of predictor variables of L. pardinus (Mid-Holocene Past Model 1) A: AUC values of the Mid-Holocene (past model 1). B: Jackknife test for the relative importance of bioclimatic variables (Mid-Holocene past model 1).

A

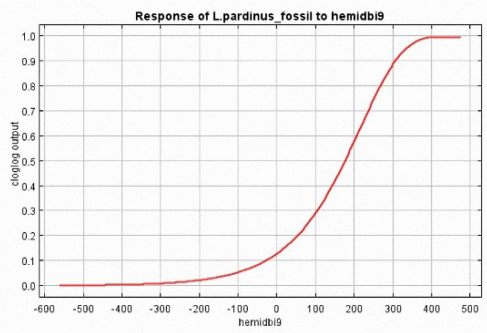

B

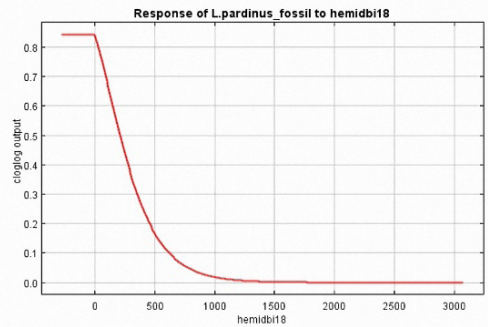

C

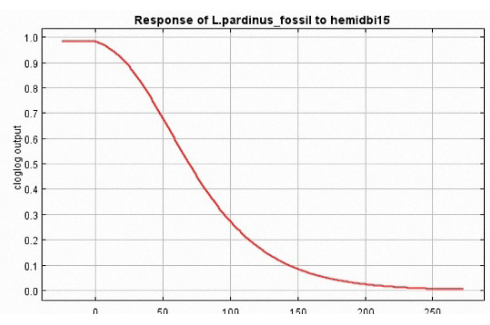

Fig. 15 Response curves from Mid_Holocene (past 1) model. A: hemidbi9 (Bio9). B: hemidbi18 (Bio18). C: hemidbi15 (Bio15). 


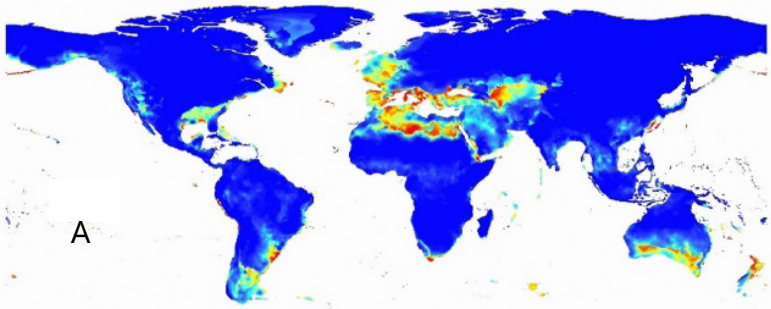

Lynx pardinus

Last Glacial Maximum (about 22,000 years ago) Past Model 1

Value

High : 1

Low : 0

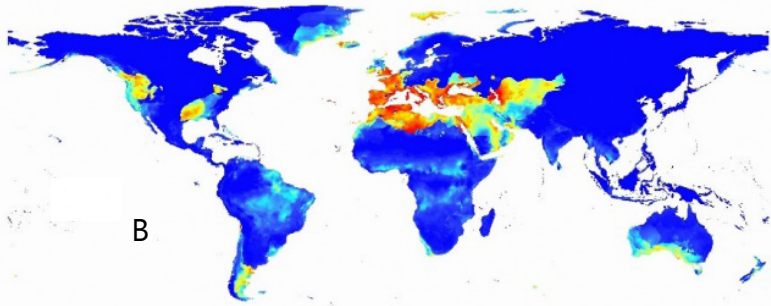

Lynx pardinus

Mid-Holocene (About 6000 years ago) Past Model I

Value ${ }_{\text {High : } 1}$

Low : 0

Fig. 16 Climatic habitat suitability maps for Lynx pardinus. A: LGM past model 1. B: Mid-Holocene past model 1.

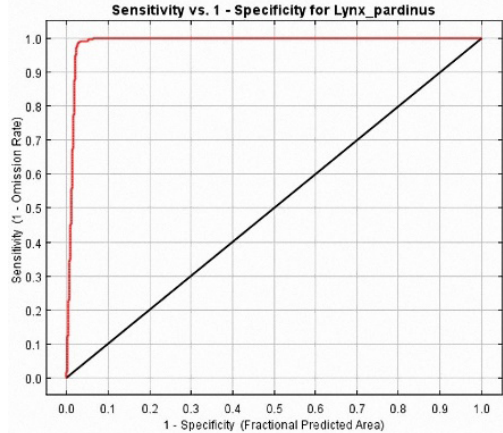

A

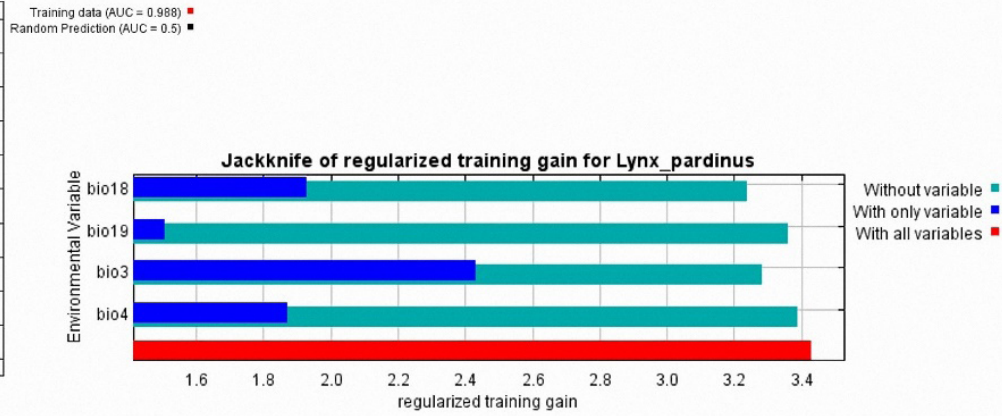

B

Fig. 17 Sensitivity vs. 1-specificity graphic and results of jackknife evaluations of relative importance of predictor variables of L. pardinus (Current Model) A: AUC values of the Current Model. B: Jackknife test for the relative importance of bioclimatic variables (Current Model).

A
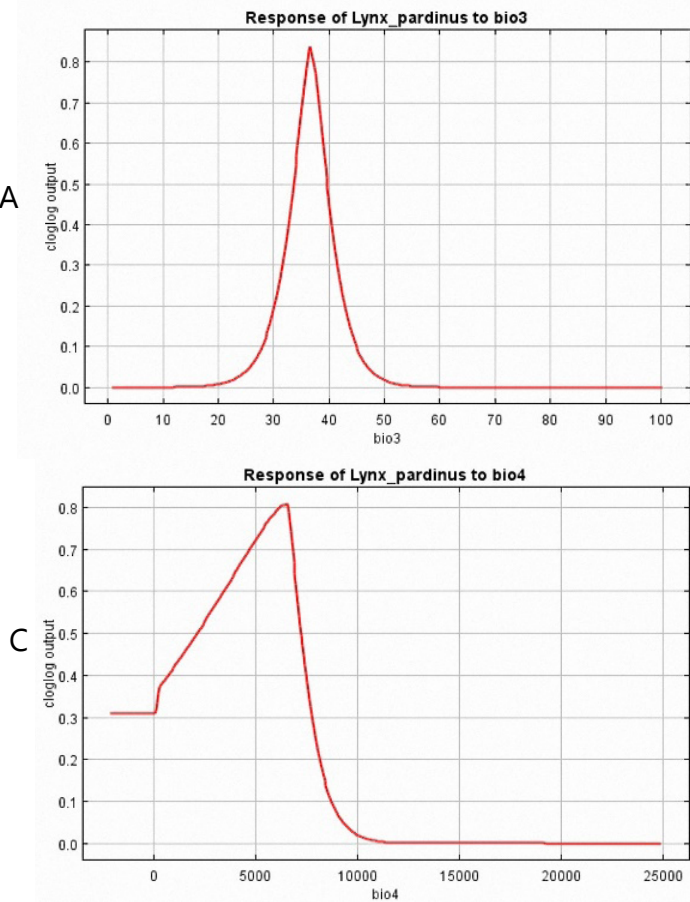

B
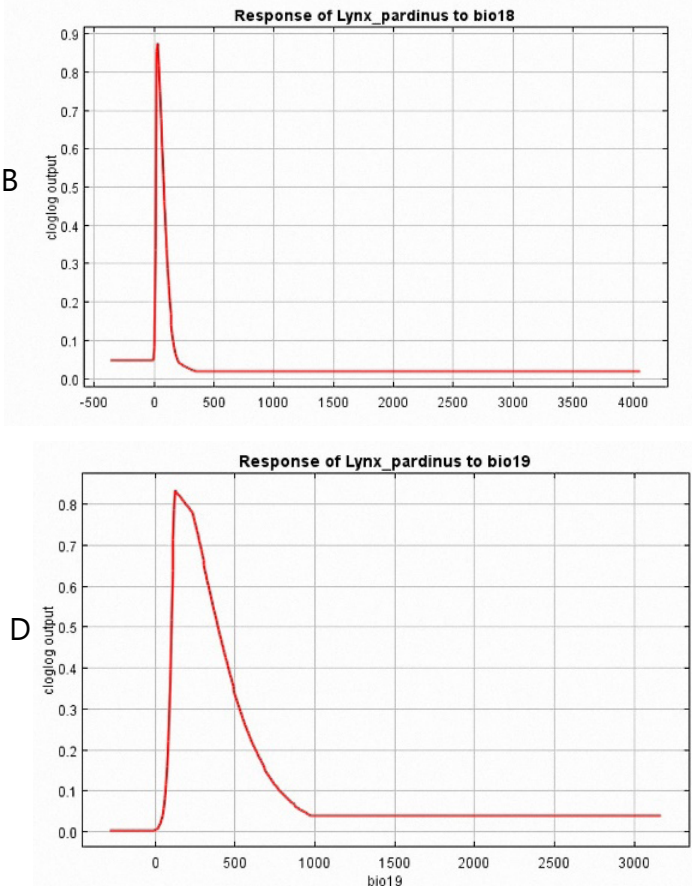

Fig. 18 Response curves from Current Model. A: Bio3. B: Bio18. C: Bio4. D: Bio19. 


\section{Past model 2}

The Past Model 2 was created by projecting the Current Model into the past. The Last Glacial Maximum (22000 years ago): During this period, it was seen that there were favorable climatic conditions for $L$. pardinus in the Iberian Peninsula, Greece as well as in the south and west of Anatolian and some parts of North Africa (Fig. 21A). MidHolocene (6000 years ago): When the model map of this period was examined, it was seen that the areas in the south and southwest of the Iberian Peninsula provided favorable climatic conditions for L. pardinus (Fig. 21B).

\section{DISCUSSION}

There is a different distribution between the Past 1 Model and the Past 2 Model maps. The reason for this is that the Past 1 model consists of the result of analysis made using fossil data and historical climate scenarios, and the Past 2 model is formed as a result of the projection made to the past with living data. In this section, Past 1 model is taken into consideration for interpretations on historical climate change and distributions.

When mammalian fossils from the Pleistocene period were compared, it was found that carnivores did not have a clear preference for climate (Von Koenigswald, 2002). According to our results, L. pardinus, one of the two wild cat species found to have fossils in the Iberian Peninsula during the LGM era, only expanded its distribution to the middle and western France, although favorable climatic conditions occurred throughout the Mediterranean during the LGM and Mid-Holocene periods. There are fossil records which proved that L. pardinus lived in France 3,000 years ago (Sommer and Benecke, 2006). L. pardinus, which could not expand its distribution towards climatic suitable habitats, limited its distribution to the Iberian Peninsula. This may be related to the fact that it had a small variety of nutrients and specialized only on hunting the European Rabbit, that the competition was low and that it used a habitat full of bushes (Ferreras et al., 2010). L. Iynx, another species with fossil records in the Iberian Peninsula, expanded its distribution to many climatically suitable and unsuitable habitats. This distribution was especially northward and was distributed throughout the Palearctic region. In other words, according

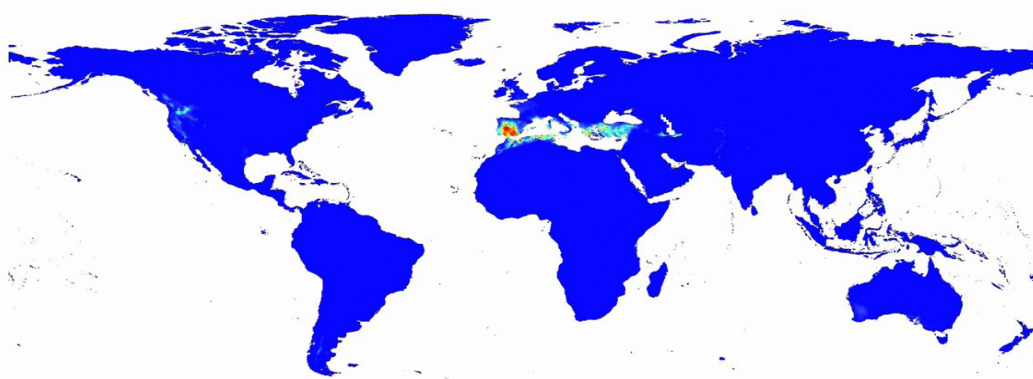

Fig. 19 Climatic habitat suitability maps for Lynx pardinus current model.

\section{Lynx pardinus}
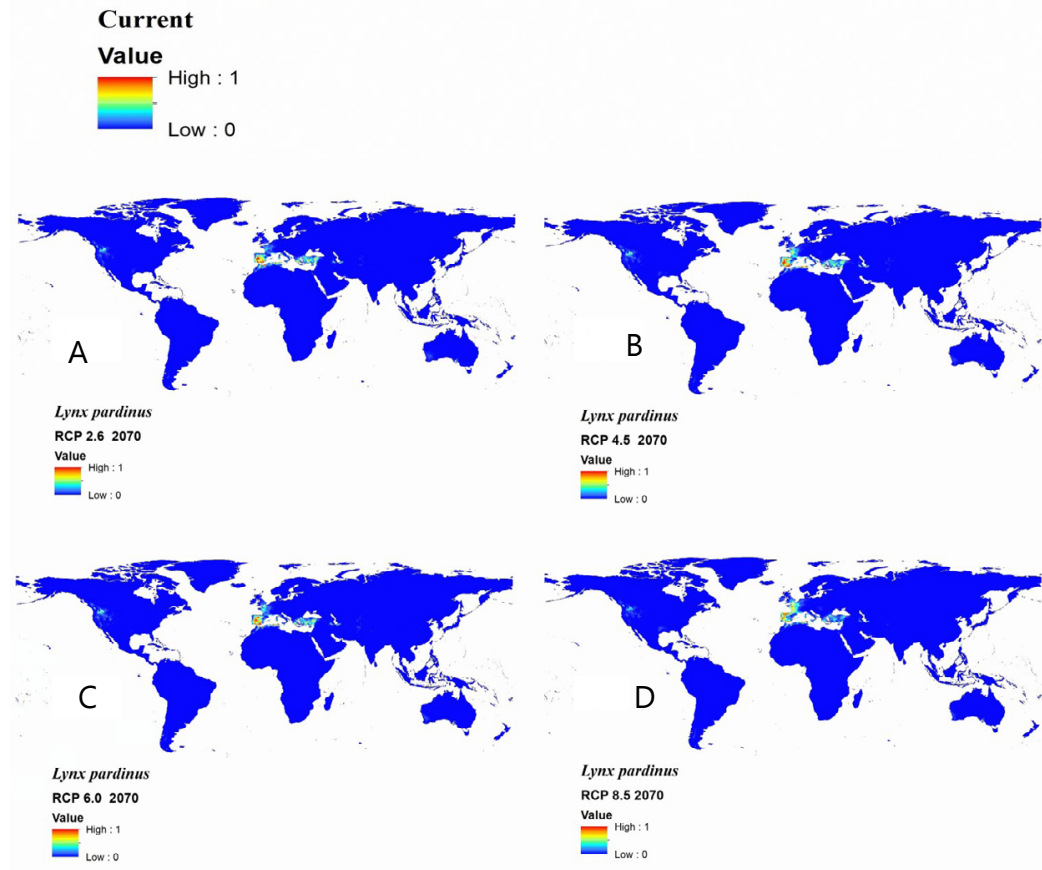

Fig. 20 Climatic habitat suitability maps for Lynx pardinus. A: RCP2.6 2070. B RCP4.5 2070. C: RCP6.0 2070. D: RCP8.5

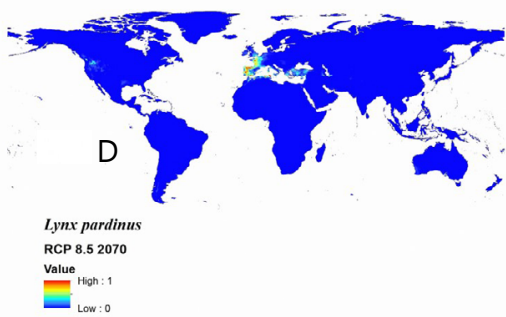
2070 


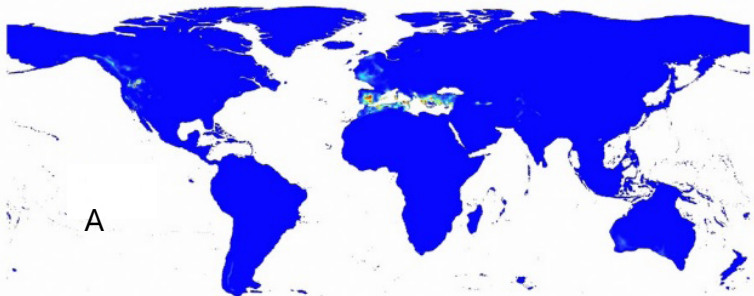

Lynx pardinus

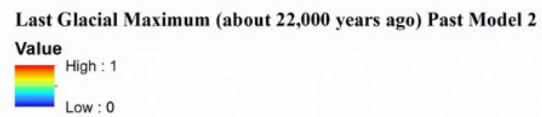

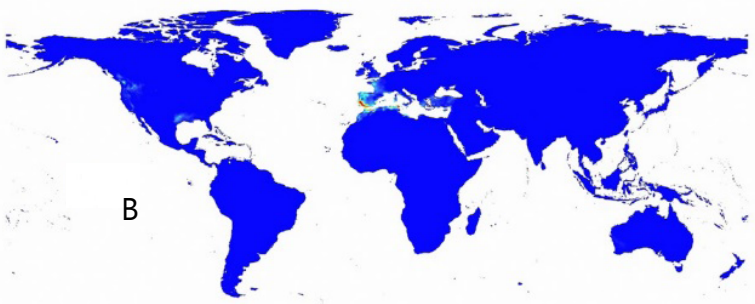

Lynx pardinus

Mid-Holocene (About 6000 years ago) Past Model 2

Value

High : 1

Fig. 21 Climatic habitat suitability maps for Lynx pardinus. A: LGM past model 2. B: Mid-Holocene past model 2.

to both our results and fossil records, L. Iynx was like seem not affected by Palaeoclimatological change. The reason for this is that L. lynx adapted to different ecosystems due to its high nutritional prey variety (Mengüllüoğlu et al., 2018). The prey type for both species appears as the factor affecting distribution during Paleoclimatological change (LGM-Mid Holocene). On the contrary, both "past model 1 " and "current model" results show that there is actually an evident climate preference. Bio6 variant for L. lynx species is very important for all models. In other words, L. Iynx has survived until today by adapting to the habitats in areas where winter conditions occur under zero degrees Celsius. When we examine the models obtained for $L$. pardinus, it is seen that it has existed in an area that has transformed into a Mediterranean climate from the past (LGM-Mid Holocene) to today. Whether these situations are directly related to two wild cats or their prey and vegetation, it does not change the fact that there is a clear climate preference.

Deforestation in Europe has been affecting mammal distribution for 5000 years (Von Arx, 2004). Decrease in suitable habitats lead wildlife populations to become smaller and more isolated. This, in particular, triggers carnivores to become extinct because carnivores need adjacent suitable habitats to increase their distribution and mobility (Ripple et al., 2014). According to our results, L. Iynx populations are not in balance with habitat suitability. In this case, anthropogenic factors also affect lynx distribution. In the studies conducted, it was observed that a large part of the appropriate habitats could not be filled by L. Iynx (Magg et al., 2016).

Anthropogenic climate change that will be encountered in the next 50 years may occur faster than historical climate change and far beyond our experience (Wiens et al., 2009). Therefore, I argue that this rapid change of climate might affect these two kinds of lynxes indirectly. Fifty years later, suitable climatic conditions for L. pardinus will decrease in its current habitat and potentially suitable areas will emerge in western France. L. pardinus, which has survived with human intervention in the recent past and continues its life with captive breeding, will only be able to reach new suitable climate habitats if they are placed there with the help of people. The impact of anthropogenic climate change on vegetation and the European rabbit is controversial. On the other hand, recent studies have shown that the most important factor that creates the genetic difference in L. Iynx is winter conditions (Schmidt et al., 2011). Genetic variations of L. Iynx will decrease if proper winter conditions do not occur. According to model results, apart from the north, the Alps, Carpathians, Caucasus and North Anatolia will serve as shelters for other L. lynx populations under the influence of climate change in the future. Because the preferred winter conditions seem to be able to continue in these areas. This will support genetic differences. According to a study conducted in Iran, according to the carbon dioxide emission scenarios, it is stated that the appropriate habitats of L. Iynx will be lost by $26-73 \%$ in 2070 , and that suitable habitats will be available only in northern Iran (Mahdavi et al., 2020). Another situation is related to whether the spread of pathogens causing epidemic diseases in mammals will be accelerated under the influence of anthropogenic climate change and to whether there will be a possibility of new pathogens which will move from south and north and against which no immunity will not have been developed yet because it will be encountered for the first time. According to a study conducted in recent years, changing climate and land use has indicated that by changing geographic distributions in wildlife, viral sharing among new species communities and previously isolated species will accelerate. It is also stated that most of the predicted viral shares will be driven by carnivores (Carlson et al., 2020). This is a scenario which can have negative consequences for L. pardinus specializing only on European rabbit hunting and whose genetic variation is reduced.

In brief, anthropogenic climate change will occur faster than paleoclimatic events and will not allow time for the adaptation mechanism. Incidents, such as possible changes in vegetation; climate sensitivity of mammals that make up the diet of lynxes; changes in genetic variation; rapid spread of mammalian pathogens; and increased habitat fragmentation along with an increase in the human population, will occur due to climate change and negatively affect lynx populations.

\section{CONCLUSION}

In order for species protection plans to succeed, it is necessary to protect habitats in which different species live. In order to minimize the effects of the anthropic climate change that threaten these natural habitats, it is now necessary to obtain energy from renewable energy sources instead of fossil fuels. Preventing deforestation is also very important. If climate change scenarios take place, 
L. pardinus, which has a narrow distribution, will lose some of its climatically suitable habitats and will, therefore, be affected by such a situation. L. pardinus can be transported and placed in potentially suitable areas in western France within a period of 50 years. L. Iynx will survive future climate change with less loss due to its higher ecological tolerance. However, deforestation should also be prevented to protect this species. Ecological bridges and passages should be constructed against habitat fragmentation in areas with high human density (highway, tourism, settlement, etc.).

\section{AUTHORSHIP CONTRIBUTION}

\author{
Project Idea: AK \\ Funding: AK \\ Database: AK \\ Processing: AK \\ Analysis: AK \\ Writing: AK \\ Review: AK
}

\section{REFERENCE}

AKYOL, A.; ÖRÜCÜ, Ö. K. Investigation and evaluation of stone pine (Pinus pinea $\mathrm{L}$.) current and future potential distribution under climate change in Turkey. Cerne, 25.4: 415-423, 2019.

CARLSON, C. J.: ALBERY, G. F.: MEROW, C.: TRISOS, C. H.; ZIPFEL, C. M.; ESKEW, E. A.; KEVIN, J. O.; NOAM R.; BANSÁL, S. Climate change will drive novel cross-species viral transmission. BioRxiv, 2020.

ELITH, J.; PILLIPS, S. J.; HASTIE, T.; DUDIK, M.; CHEE, Y. E.; Yates, C. J. A statistical explanation of MaxEnt for ecologists. Diversity and Distributions, 17(1), 43-57, 2011

FERRERAS, P.; TRAVAINI, A.; ZAPATA, S. C.; DELIBES, M. Short-term responses of mammalian carnivores to a sudden collapse of rabbits in Mediterranean Spain. Basic and Applied Ecology, 12(2), 116-124, 2011

GAIJI, S.; CHAVAN, V.; ARINO, A. H., OTEGUI, J.; HOBERN, D.: SOOD, R Robles, E. Content assessment of the primary biodiversity data published through GBIF network: status, challenges and potentials. Biodiversity Informatics, 8(2), 2013.

GUISAN, A.; THUILLER, W. Predicting species distribution: offering more than simple habitat models. Ecology letters, 8.9: 993-1009, 2005.

HENDRICK, L. R. F.; MCGARVEY, D. J. Climate Change and MountaintopRemoval Mining: A MaxEnt Assessment of the Potential Threat to West Virginian Fishes. Northeastern Naturalist, 26.3: 499-522, 2019

HEWITT, G. Ice ages: species distributions, and evolution. In: Evolution on planet Earth. Academic Press, 2003. p. 339-361.

HIJMANS, R. J.; CAMERON, S. E.; PARRA, J. L.; JONES, P. G.; JARVIS, A Very high-resolution interpolated climate surfaces for global land areas International Journal of Climatology: A Journal of the Royal Meteorological Society, 25(15), 1965-1978, 2005

IPCC 2013 FIFT ASSESSMENT REPORT. Available at: ipcc.ch/assessmentreport/ar5/. Accessed in: January 7th 2020.

KIRAÇ, A.; MERT, A. Will Danford's lizard become extinct in the future? Polish Journal of Environmental Studies, 28.3: 1741-1748, 2019.

KOC, D. E.; SVENNING, J. C.; AVCl, M. Climate change impacts on the potential distribution of Taxus baccata L. in the Eastern Mediterranean and the Bolka Mountains (Turkey) from last glacial maximum to the future. Eurasian Journa of Forest Science, 6.3: 69-82, 2018.

MAGG, N.; MULLER, J.; HEIBL, C.; HACLANDER, K.; WOLFL, S.; WOLFL, M. BUFKA, L.; CERENY, J.: HEURICH, M. Habitat availability is not limiting the distribution of the Bohemian-Bavarian Lynx lynx population. Oryx, 50(4) $742-752,2016$
MAHDAVI, T.; SHAMS-ESFANDABAD, B.; TORANJZAR, $H_{\text {.; }}$ ABDI, N.; AHMADI, A. Potential impact of climate change on the distribution of the Eurasian Lynx (Lynx lynx) in Iran (Mammalia: Felidae). Zoology in the Middle East, 1-11, 2020.

MENGÜLLÜOĞLU, D.; AMBARLI, H.; BERGER, A.; HOFER, H. Foraging ecology of Eurasian lynx populations in southwest Asia: Conservation implications for a diet specialist. Ecology and evolution, 8(18), 9451-9463, 2018.

NOGUÉS-BRAVO, D. Predicting the past distribution of species climatic niches. Global Ecology and Biogeography, 18.5: 521-531, 2009.

PHILLIPS, S. J.; ANDERSON, R. P.; SCHAPIRE, R. E. Maximum entropy modeling of species geographic distributions. Ecological modelling, 190(34), 231-259, 2006

PHILLIPS, S. J.: ANDERSON, R. P: DUDÍK, M. SCHAPIRE, R. E. BLAIR, M. E. Opening the black box: An open-source release of Maxent. Ecography, 40(7), 887-893, 2017.

PREAU, C.; TROCHET, A.; BERTRAND, R.; ISSELIN-NONDEREU, F. Modeling potential distributions of three European amphibian species comparing ENFA and Maxent. Herpetological Conservation and Biology, 13(1), 91-104, 2018.

QIAN, T.; CHI, Y., XI, C., LI, Z., Wang, J. Changes in the Historical and Current Habitat Ranges of Rare Wild Mammals in China: A Case Study of Six Taxa of Small-to Large-Sized Mammals. Sustainability, 12(7), 2744, 2020.

RADCHUK, V.; KRAMER-SCHADT, S.; FICKEL, J.; WILTING, A. Distributions of mammals in Southeast Asia: The role of the legacy of climate and species body mass. Journal of Biogeography, 46(10), 2350-2362, 2019.

RIPPLE, W. J.; ESTES, J. A.; BESCHTA, R. L.; WILMERS, C. C.; RITCHIE, E. G.; HEBBLEWHITE, M.; Schmitz, O. J. Status and ecological effects of the world's largest carnivores. Science, 343(6167), 1241484, 2014.

SANDEL, B.; ARGE, L.; DALSSGARD, B.; DAVIES, R. G.; GASTON, K. J.; SUTHERLAND, W. J.; SVENNING, J. C. The influence of Late Quaternary climate-change velocity on species endemism. Science, 334(6056), 660-664, 2011.

SCHMIDT, K.; RATKIEWICZ, M.; KONOPIŃSKI, M. K. The importance of genetic variability and population differentiation in the Eurasian Lynx lynx for conservation, in the context of habitat and climate change. Mammal review, 41.2: 112-124, 2011

SOMMER, R. S.; BENECKE, N. Late Pleistocene and Holocene development of the felid fauna (Felidae) of Europe: a review. Journal of Zoology, 269.1: $7-19,2006$

SÜEL, H.; MERT, A.; YALCINKAYA, B. Changing potential distribution of gray wolf under climate change in lake district, Turkey. Applied Ecology and Environmental Research, 16.5: 7129-7137, 2018.

UNTALAN, M. Z. G.; BURGOS, D. F. M.; MARTINEZ, K. P. Species Distribution modelling of two species endemic to the Philippines to show the applicability of maxent. International Archives of the Photogrammetry, Remote Sensing \& Spatial Information Sciences, 2019

VON ARX, Manuela (ed.). Status and conservation of the Eurasian lynx (Lynx lynx) in Europe in 2001. Kora, 2004. 330p.

VON KOENIGSWALD, W. Mammalian faunas from the interglacial periods in Central Europe and their stratigraphic correlation. In: Developments in Quaternary Sciences. Elsevier, 2007. p. 445-454.

WIENS, J. A.; STRALBERG, D.; JONGSOMJIT, D.; HOWELL, C. A.; SNYDER, M. A. Niches, models, and climate change: assessing the assumptions and uncertainties. Proceedings of the National Academy of Sciences, 106(Supplement 2), 19729-19736, 2009 